\title{
Knowledge, attitudes and practices (KAP) regarding menstruation among girls in Aurangabad, India and their correlation with sociodemographic factors
}

\author{
Varsha Deshmukh ${ }^{1}$, Gurpreet Kaur Sandhu ${ }^{2 *}$, Laxmi Rachakonda ${ }^{3}$, \\ Manisha Kakde ${ }^{4}$, Andurkar S. P. 5
}

\begin{abstract}
${ }^{1}$ Department of Obstetrics and Gynecology, Government Medical College and Cancer Hospital, Aurangabad, Maharashtra, India

${ }^{2}$ Department of Obstetrics and Gynecology, C. S. M. S. S. Institute, Aurangabad, Maharashtra, India

${ }^{3}$ Department of Obstetrics and Gynecology, MGM Medical College, Aurangabad, Maharashtra, India

${ }^{4}$ Department of Obstetrics and Gynecology, Anantshree Hospital, Aurangabad, Maharashtra, India

${ }^{5}$ Department of PSM, Government Medical College, Aurangabad, Maharashtra, India
\end{abstract}

Received: 30 December 2018

Accepted: 05 December 2019

*Correspondence:

Dr. Gurpreet Kaur Sandhu,

E-mail: singh.chiranjeev2@gmail.com

Copyright: () the author(s), publisher and licensee Medip Academy. This is an open-access article distributed under the terms of the Creative Commons Attribution Non-Commercial License, which permits unrestricted non-commercial use, distribution, and reproduction in any medium, provided the original work is properly cited.

\section{ABSTRACT}

Background: Menstruation has always been surrounded by different perceptions throughout the world. Nowadays, there is some openness toward menstruation, but differences in attitude still persist between different populations depending upon the education, socioeconomic status and the surroundings. We conducted this study to assess the knowledge regarding menstruation, their attitudes and the practises undertaken by the young girls of India .A prewritten questionnaire was distributed to these girls and the answers were analysed.

Methods: A school based cross-sectional study design was employed in Aurangabad, Maharashtra. A multi stage sampling technique was used to select 1000 female high school and junior college and pharmacy college students. Data collection was carried out from May 2018 to August 2018 using a pre- tested structured questionnaire. The data were entered into a computer using Epi-info version 3.5.1 and then exported to SPSS for Windows version 20.0 for analysis. Bivariate and multivariate logistic regression analysis was done at $95 \%$ confidence interval.

Results: In this study 682and 552 respondents had good knowledge and practice of menstruation respectively. The findings of the study showed a significant positive association between good knowledge of menstruation and educational status of mothers $(\mathrm{AOR}=1.51,95 \% \mathrm{CI}=1.02-2.22),(\mathrm{AOR}=2.42,95 \% \mathrm{CI}: 1.64-3.56)$. Educational status of the mother $(\mathrm{AOR}=2.03,95 \% \mathrm{CI}=1.38-2.97)$, revealed significant positive association with good practice and attitude of menstrual process.

Conclusions: The findings showed that the knowledge and practice of menstruation is low. Hence awareness programmed should be conducted in schools regularly. Participation of mothers can also add to the knowledge and good practice scores of the young girls.

Keywords: Attitude, Knowledge, Menstruation, Practice

\section{INTRODUCTION}

Adolescent girls constitute a vulnerable group not only with respect to their social status but also in relation to their health. In this regard, menstruation is regarded unclean or dirty in society. Menstruation is accompanied by a cultural taboo in almost every society in the world. It can be manifested by perception of uncleanliness, and the 
resulting stigma means that discussion about periods often happens in euphemisms, when discussed at all. ${ }^{1}$ Although very common issue of everyday life, menstruation is associated with many menstruations negative attitude in young girls. This also has an impact on the menstrual care and hygiene issues in this population. To this effect, the practice of good menstrual hygiene reduces the incidence of reproductive tract infection (RTI). Thus, the consequences of RTIs are severe and may result in significant negative impact to a woman's health including chronic pelvic pain, dysmenorrhea (painful periods) and in severe cases infertility. Reproductive tract infections, which have become a silent epidemic that devastates women's lives is closely related to poor menstrual hygiene. ${ }^{2}$ Every year approximately $10 \%$ of women worldwide are exposed to genital infections including urinary tract infections and bacterial vaginosis, and $75 \%$ of women have a history of a genital infection. Specifically, the common risk factors for vaginal infections include pregnancy and poor hygiene (both perineal and menstrual hygiene). ${ }^{3}$ The media is teeming with the information about menstruation and the scientific basics of it. The young population is seen to be trapped and confused due to the different schools of thoughts at home and the outer world. This indicates an urgency to investigate girls' menstrual needs, to inform effective responses and educate them about the right strategies of menstrual hygiene, attitudes and practices. ${ }^{4}$ Indeed, it is time to talk about menstruation. To address the needs of women and girls worldwide, this conversation should be informed by a strong, cross-sectoral evidence base, supported by outlets and journals study.

\section{METHODS}

School based study was employed from May 2018 to August 2018 among high school girls of Maulana Azad Girls secondary school, Aurangabad, Shankarrao Chavhan college of pharmacy and Clover Dale school, Aurangabad.

\section{Inclusion criteria}

- The girls who attained menarche were included for the study.

\section{Exclusion criteria}

- Girls with visual impairment, evening class students and those who were ill and incapable to provide informed consent were excluded from the study.

To collect data self-administered questionnaires were employed. After reviewing relevant literature questionnaires were adapted and modified. A predesigned questionnaire was distributed to the girls and were asked to fill it. A health talk regarding menstrual hygiene, eating habits, dressing sense, role of exercise and other vital issues was given by imminent speakers.
The sample size was determined using a formula for estimation of single population proportion with the assumption of $95 \%$ confidence interval, $5 \%$ margin of error, and prevalence of knowledge about menstruation at $51.36 \%$, to compensate for the non-response rate, $10 \%$ of the determined sample was added up on the calculated sample size and the final sample size was found to be 1000. The sampling frame was obtained from the student registration books of the respective schools. ${ }^{5}$ The questionnaire was collected after the students filled it. Students' menstrual knowledge score was calculated out of the 5 knowledge specific questions (Table 2). Each correct response earned one point, whereas any wrong or don't know response attracted no mark and thus the sum score of knowledge was calculated (5 points) Accordingly, the mean score of menstrual knowledge $(3.8 \pm 1.67)$ was used to decide the cutoffs of the rank. Good knowledge of menstruation was given to those respondents who scored 3-5 points and poor knowledge of menstruation was given to those respondents who scored 0-3 points. Students' cultural practice of menstruation score was calculated out of the practice specific questions (Table2). Each correct response earned one point, whereas any wrong or don't know response attracted no mark. In here, the sum score of practice was calculated (6 points). Where, the mean score of practice of menstrual practices $(3.1 \pm 1.57)$ was used to decide the cutoffs of the rank. Good practice of menstrual was given to those respondents who scored 4-6 points and poor practice of menstrual hygiene was given to those respondents who scored $0-3$ points. Similarly attitude towards menstruation was scored, total score being 7 . After calculation of good and bad practice scores, they were corelated with the sociodemographic features of the girls.

\section{Statistical analysis}

Each completed questionnaire was coded on pre-arranged coding sheet to minimize errors. The incompletely filled questionnaires were rejected. Data entered into a computer using Epi-info window version 3.5.1 statistical program by data entry operator. Then the data were exported to SPSS Windows version 20.0 for analysis. The descriptive analysis including proportions, percentages, frequency distribution and measures of central tendency was done. An ethical clearance was obtained by the ethical committee of the respective schools and the questionnaire was reviewed by them. Permission was secured from each high school through a formal letter. School directors and directresses were briefed on the relevance and objectives of the study. The privacy of the answers was maintained.

\section{RESULTS}

A total student population of 1165 girls were given questionnaire. About 165 forms were rejected as they were filled incompletely. 1000 forms were analysed. Table 1 shows that $55.7 \%$ girls belonged to an age group 
of 16 to 20years, $62.4 \%$ came from a nuclear family, about $45 \%$ girls had illiterate mothers and $8 \%$ girls were widow at a tender age. This table shows that the large number of students had mothers who were illiterate or barely had any education. Although $93.4 \%$ girls were unmarried, there were some married girls also. Only $15.6 \%$ of the study population belonged to a higher socioeconomic status, whereas $24.4 \%$ belonged to allow socioeconomic status. A $96.2 \%$ girls were students, other $3,8 \%$ had to work to support themselves.

Table 1: Demographic profile of girls.

\begin{tabular}{|c|c|c|c|}
\hline & & $\mathrm{N}=1000$ & $\%$ \\
\hline \multirow{4}{*}{ Age-group } & $\leq 15$ year & 348 & 34.8 \\
\hline & $16-20$ year & 557 & 55.7 \\
\hline & 21-25 year & 95 & 9.5 \\
\hline & Total & & 100 \\
\hline \multirow{6}{*}{ Socio-economic status } & Grade $1(\geq 6391)$ & 156 & 15.6 \\
\hline & Grade 2 (3196-6390) & 125 & 12.5 \\
\hline & Grade 3(1971-3195) & 269 & 26.9 \\
\hline & Grade 4(959-1916) & 206 & 20.6 \\
\hline & Grade $5(\leq 958)$ & 244 & 24.4 \\
\hline & Total & & 100 \\
\hline \multirow{3}{*}{ Type of family } & Nuclear & 624 & 62.4 \\
\hline & Joint & 376 & 37.6 \\
\hline & Total & & 100 \\
\hline \multirow{4}{*}{ Religion } & Hindu & 638 & 63.8 \\
\hline & Muslim & 312 & 31.2 \\
\hline & Other & 50 & 5.0 \\
\hline & Total & & 100 \\
\hline \multirow{4}{*}{$\begin{array}{l}\text { Educational status of } \\
\text { mother }\end{array}$} & Secondary to Higher & 56 & 5.6 \\
\hline & Middle & 125 & 12.5 \\
\hline & Primary & 369 & 36.9 \\
\hline & Illiterate & 450 & 45.0 \\
\hline \multirow{6}{*}{ Marital status } & Total & & 100 \\
\hline & Married & 35 & 3.5 \\
\hline & Unmarried & 934 & 93.4 \\
\hline & Widow & 8 & .8 \\
\hline & Separated & 23 & 2.3 \\
\hline & Total & & 100 \\
\hline \multirow{5}{*}{ Occupation } & Student & 962 & 96.2 \\
\hline & Part time job & 17 & 1.7 \\
\hline & Tuitions etc & 13 & 1.3 \\
\hline & Self-employment & 8 & 0.8 \\
\hline & Total & & 100 \\
\hline
\end{tabular}

This table depicts the true picture of a typical Indian school where students come from all socioeconomic classes with different backgrounds and cultures (Table 1). Table 2 shows that $86.9 \%$ girls got the information through the mother, fifty-three $(5.3 \%)$ of the respondents reported to have received information regarding menstruation from their sisters.

The probability is that the information received was superficial on the basis that, if a girl matures, she gets a monthly period without understanding the context of menstruation in relation to conception and contraception. A $60.2 \%$ had discomfort to have menses and $22.7 \%$ were actually scared when they had menses. The negative reaction towards this natural process is notable in this study. About $68.2 \%$ had the correct knowledge of source of bleeding during menses.

But $22 \%$ did not know the source of bleeding in menstrual cycle. About $88.7 \%$ thought that menses are physiological. Majority $(65.4 \%)$ girls thought that pads should be changed after 3-6 hours. However, 212 girls thought that pad should be changed after 6 hours which may be a cause for unhygienic menstrual behaviour of this girls. Knowledge of the girls regarding menstruation was assessed in Table 2. 
Table 2: Knowledge of girls.

\begin{tabular}{|l|l|l|l|}
\hline \multirow{2}{*}{ Who was the primary source of information? } & Mother & 869 & 86.9 \\
\hline & Sister & 53 & 5.3 \\
\hline \multirow{2}{*}{ What was your reaction to first menstruation? } & Relatives & 29 & 2.9 \\
\hline & Neighbor/ friend & 59 & 5.9 \\
\hline \multirow{2}{*}{ What is the source of menstrual bleeding? } & Scared & 227 & 22.7 \\
\hline \multirow{2}{*}{ What do you think about menstrual process? } & Usual & 171 & 17.1 \\
\hline \multirow{2}{*}{ What should be the frequency of change of soakage material? } & Discomfort & 602 & 60.2 \\
\hline & Uterus & 682 & 68.2 \\
\hline & Urinary bladder & 98 & 9.8 \\
\hline & Don't know & 220 & 22.0 \\
\hline & Physiological & 887 & 88.7 \\
\hline & Curse of God/ disease & 113 & 11.3 \\
\hline
\end{tabular}

Table 3: Cultural practices of girls.

\begin{tabular}{|c|c|c|c|}
\hline & & Number & Percentage \\
\hline \multirow{2}{*}{ Do you bath during menstrual cycle? } & Yes & 919 & 91.9 \\
\hline & No & 81 & 8.1 \\
\hline \multirow{4}{*}{ Is food restricted in any form? eg pickle, sabji } & Touching & 116 & 11.6 \\
\hline & Cooking & 123 & 12.3 \\
\hline & Eating & 109 & 10.9 \\
\hline & All & 116 & 11.6 \\
\hline \multirow{2}{*}{ Are you allowed to sleep on the floor? } & Yes & 329 & 32.9 \\
\hline & No & 771 & 77.1 \\
\hline \multirow{2}{*}{ Do you perform routine household activity? } & Yes & 878 & 87.8 \\
\hline & No & 122 & 12.2 \\
\hline \multirow{2}{*}{ Do you face any kind of religious restriction? } & Yes & 407 & 40.7 \\
\hline & No & 593 & 59.3 \\
\hline \multirow{2}{*}{ Any other practices? playing, social functions } & Yes & 26 & 2.6 \\
\hline & No & 974 & 97.4 \\
\hline
\end{tabular}

Table 3 shows that $91.9 \%$ girls bathed during menses. However, there were few girls $8.1 \%$ who were not practicing good hygienic practices in this era.

A 464 participants were not allowed to cook or touch the food articles like pickle etc indicating a change in eating habits during menses is still practiced.

About $87.8 \%$ did the routine activities during menses and a $12.2 \%$ were not allowed to do the household work. This shows that a cultural influence of sitting separately during menses is practiced.

About $59.3 \%$ did not have any religious restrictions only $2.6 \%$ were not allowed to go out for social functions or to play during menses.
Practices during menstruation. Girls are largely negatively directed about cultural beliefs concerning menstruation and the ways in which they will be expected to behave in order to uphold those beliefs. This shows that we are still not out of our restrictive. The perpetuation of cultural menstrual taboos that menstruation is 'dirty', that it must be hidden is still prevalent in our society.

Table 4 shows that the attitude of the participants regarding menstruation.is determined by the various factors around. The present study revealed that the myths related to menstrual cycle still exist. In present study it is observed that $28.7 \%$ girls during menstrual cycle, follow the restrictions like not going to temples. Similarly, restriction of activities like not cooking food was agreed upon by $48.15 \%$ participants 
Table 4: Attitude of girls.

\begin{tabular}{|c|c|c|c|}
\hline Question & Likert scale & $N=951$ & $\%$ \\
\hline \multirow{6}{*}{ Women can enter temple/pray during menstruation } & Strongly disagree & 231 & 23.23 \\
\hline & Disagree & 155 & 15.24 \\
\hline & Neutral & 153 & 15.03 \\
\hline & Agree & 179 & 17.77 \\
\hline & Strongly agree & 282 & 28.7 \\
\hline & Total & 1000 & 100 \\
\hline \multirow{6}{*}{ Women can enter kitchen/cook food during menstruation } & Strongly disagree & 17 & 1.78 \\
\hline & Disagree & 46 & 4.62 \\
\hline & Neutral & 85 & 8.51 \\
\hline & Agree & 364 & 36.9 \\
\hline & Strongly agree & 488 & 48.15 \\
\hline & Total & 1000 & 100 \\
\hline \multirow{6}{*}{ Women can take bath during menstruation } & Strongly disagree & 26 & 2.62 \\
\hline & Disagree & 33 & 3.36 \\
\hline & Neutral & 56 & 5.67 \\
\hline & Agree & 318 & 31.54 \\
\hline & Strongly agree & 567 & 56.78 \\
\hline & Total & 1000 & 100 \\
\hline \multirow{6}{*}{ Women can wash hair during menstruation } & Strongly disagree & 70 & 7.04 \\
\hline & Disagree & 114 & 11.46 \\
\hline & Neutral & 140 & 14.09 \\
\hline & Agree & 354 & 35.12 \\
\hline & Strongly agree & 322 & 32.28 \\
\hline & Total & 1000 & 100 \\
\hline \multirow{6}{*}{ Women can sleep on same beds as others during menstruation } & Strongly disagree & 33 & 3.36 \\
\hline & Disagree & 94 & 9.46 \\
\hline & Neutral & 93 & 9.25 \\
\hline & Agree & 394 & 39.43 \\
\hline & Strongly agree & 386 & 38.48 \\
\hline & Total & 1000 & 100 \\
\hline \multirow[t]{6}{*}{ Women can touch pickle during menstruation } & Strongly disagree & 83 & 8.3 \\
\hline & Disagree & 127 & 12.72 \\
\hline & Neutral & 182 & 18.29 \\
\hline & Agree & 289 & 28.97 \\
\hline & Strongly agree & 319 & 31.96 \\
\hline & Total & 1000 & 100 \\
\hline \multirow{6}{*}{ Women can have sexual intercourse during menstruation } & Strongly disagree & 56 & 5.67 \\
\hline & Disagree & 119 & 11.88 \\
\hline & Neutral & 176 & 17.45 \\
\hline & Agree & 351 & 35.12 \\
\hline & Strongly agree & 298 & 29.86 \\
\hline & Total & 1000 & 100 \\
\hline
\end{tabular}

Factors like taking a bath and washing hair which account for the basic hygiene were not practiced by all of the participants. The attitude solely depends upon the information provided to her by her surroundings. Factors like touching pickle and sharing beds received a very positive response, as majority of them agreed strongly or agreed. Opinion about having sexual intercourse during menstruation was confusing to them as it was a forbidden domain to talk with family. Table 5 shows that there is a significant association between practice and type of family, religion and educational status. So, we considered subjects whose practice's score was $\leq 3$ as bad practice and score $\geq 4$ as good practice. And later applied chi Square accordingly. $\mathrm{P}$ value of 0.05 was considered significant. 
Table 5: Distribution of adolescent girl's practice according to socio-demographic characteristics.

\begin{tabular}{|c|c|c|c|c|c|c|}
\hline & Bad practice & Good practice & Total & Chi square & df & p \\
\hline \multicolumn{7}{|l|}{ Family } \\
\hline Nuclear & 235 & 363 & 598 & \multirow{3}{*}{4.674} & \multirow{3}{*}{1} & \multirow{3}{*}{0.031} \\
\hline Joint & 164 & 189 & 353 & & & \\
\hline Total & 399 & 552 & 951 & & & \\
\hline \multicolumn{7}{|l|}{ Religion } \\
\hline Hindu & 222 & 407 & 629 & 54.25 & 2 & 0 \\
\hline Muslim & 164 & 108 & 272 & & & \\
\hline Others & 13 & 37 & 50 & & & \\
\hline Total & 399 & 552 & 951 & & & \\
\hline \multicolumn{7}{|l|}{ Marital status } \\
\hline Married & 10 & 19 & 29 & 2.107 & 3 & 0.55 \\
\hline Unmarried & 379 & 512 & 891 & & & \\
\hline Widow & 3 & 5 & 8 & & & \\
\hline Separated & 7 & 16 & 23 & & & \\
\hline Total & 399 & 552 & 951 & & & \\
\hline \multicolumn{7}{|l|}{ Mother's education } \\
\hline Secondary or higher & 23 & 28 & 51 & 0.73 & 3 & 0.866 \\
\hline Middle & 53 & 67 & 120 & & & \\
\hline Primary & 149 & 204 & 353 & & & \\
\hline Illiterate & 173 & 252 & 425 & & & \\
\hline Total & 398 & 551 & 949 & & & \\
\hline \multicolumn{7}{|c|}{ Occupation of mother } \\
\hline Home-maker & 382 & 526 & 928 & 1.805 & 4 & 0.772 \\
\hline Student & 6 & 11 & 27 & & & \\
\hline Govt. Job & 4 & 9 & 1 & & & \\
\hline Pvt. Job & 4 & 3 & 7 & & & \\
\hline Self-employment & 3 & 3 & 6 & & & \\
\hline Total & 399 & 552 & 951 & & & \\
\hline
\end{tabular}

This table shows that positive correlation between the practices adapted during menstruation and the nuclear family, Hindu religion (Table 5). It corelated very well with the mother's educational status. Table 6 shows that there is an association between attitude and religion and marital status. So, we considered subjects whose attitude's score was $\leq 26$ as good attitude and score $\geq 27$ as bad attitude. And later applied chi square accordingly. $\mathrm{P}$ value of 0.05 was considered significant. This table shows that the attitude towards menstruation is dependent on the sociodemographic factors and corelated well with the mother's education, nuclear family (Table 6).

\section{DISCUSSION}

The current study examined KAP toward menstruation among girls and found a positive correlation with the demographic and socioeconomic status. Overall, we found that the girls had a good knowledge about the menstruation and were positive in attitude towards it. In this study, more than half $(60.9 \%)$ of the students had good knowledge about menstruation and menstrual practices. Table 1 shows that $55.7 \%$ girls were in the age group of 16 to 20 years., $71.9 \%$ belonged to the lower middle and lower socio-economic status. This is because we involved the government granted schools to get large number of girls from the society in the middle-class strata. A $62.4 \%$ girls belonged to nuclear family. This finding signifies the changing trends in urban areas with an impact on the psychological health of the young adolescents. About $45 \%$ of the mothers were illiterate in our study whereas $36.9 \%$ were primary educated. The education status of mother can hinder from overcoming traditional beliefs, misconceptions and restrictions regarding menstruation. ${ }^{6}$ In our study $96.2 \%$ girls had the luxury to be the students. The other $3.8 \%$ were either doing a part time job (in shops etc.) or helping their parents in their small-scale business. (self-employed). We also had girls who were doing tuitions or doing small time jobs to support their education or family. There are also observational studies that look at the associations between menstrual knowledge management practices and various sociodemographic and contextual characteristics (e.g., lack of privacy, water, and/or proper sanitary disposal at school). Many of these studies are school based and often compare urban versus rural schools and/or private versus public schools. ${ }^{7}$ These articles frequently conclude that menstrual management is worse for girls in rural areas and for those who attend public schools (which tend to serve families of lower 
socioeconomic status). ${ }^{8}$ Present study findings are in agreement with Kulhmann et al who also had the low socioeconomic status girls with low level of mother's education. A similar study done in western Nigeria showed that parental education was positively associated with girls' menstrual knowledge. ${ }^{9}$

Table 6: Distribution of adolescent girl's attitude according to socio-demographic characteristics.

\begin{tabular}{|c|c|c|c|c|c|c|}
\hline & Good attitude & Bad attitude & Total & Chi square & df & p \\
\hline \multicolumn{7}{|l|}{ Family } \\
\hline Nuclear & 262 & 336 & 598 & \multirow{3}{*}{3.578} & \multirow{3}{*}{1} & \multirow{3}{*}{0.059} \\
\hline Joint & 177 & 176 & 353 & & & \\
\hline Total & 439 & 512 & 951 & & & \\
\hline \multicolumn{7}{|l|}{ Religion } \\
\hline Hindu & 232 & 397 & 629 & \multirow{4}{*}{86.19} & \multirow{4}{*}{2} & \multirow{4}{*}{0} \\
\hline Muslim & 190 & 82 & 272 & & & \\
\hline Others & 17 & 33 & 50 & & & \\
\hline Total & 439 & 512 & 951 & & & \\
\hline \multicolumn{7}{|l|}{ Educational status } \\
\hline Secondary or higher & 6 & 8 & 14 & 1.251 & 3 & 0.741 \\
\hline Middle & 26 & 23 & 49 & & & \\
\hline Primary & 117 & 145 & 262 & & & \\
\hline Illiterate & 289 & 334 & 623 & & & \\
\hline Total & 438 & 510 & 948 & & & \\
\hline \multicolumn{7}{|l|}{ Marital status } \\
\hline Married & 19 & 10 & 29 & 20.608 & 3 & 0 \\
\hline Unmarried & 395 & 496 & 891 & & & \\
\hline Widow & 7 & 1 & 8 & & & \\
\hline Separated & 18 & 5 & 23 & & & \\
\hline Total & 439 & 512 & 951 & & & \\
\hline \multicolumn{7}{|l|}{ Mother's education } \\
\hline Secondary or higher & 21 & 30 & 51 & 3.063 & 3 & 0.382 \\
\hline Middle & 62 & 58 & 120 & & & \\
\hline Primary & 168 & 185 & 353 & & & \\
\hline Illiterate & 187 & 238 & 425 & & & \\
\hline Total & 438 & 511 & 949 & & & \\
\hline \multicolumn{7}{|c|}{ Occupation of mother } \\
\hline Home-maker & 413 & 495 & 908 & 4.132 & 4 & 0.388 \\
\hline Student & 11 & 6 & 17 & & & \\
\hline Govt. Job & 8 & 5 & 13 & & & \\
\hline Pvt. Job & 4 & 3 & 7 & & & \\
\hline Self-employment & 3 & 3 & 6 & & & \\
\hline Total & 439 & 512 & 951 & & & \\
\hline
\end{tabular}

According to the data obtained from the participants, $86.9 \%$ of the respondents had received knowledge about menstruation from mother (Table 2). Other resources for information were sisters, friends, neighbors etc. Out of total eight hundred eighty-seven $(88.7 \%)$ of girls knew that menstruation was a physiological process, $11.3 \%$ of the girls believed that it was a curse from God. $60.2 \%$ had discomfort during menses. More than half, six hundred eighty-two of the respondents knew the origin of the menstrual blood was from the uterus. The knowledge score was 3.63. We considered subjects whose practice's score was $\leq 3$ as bad practice and score $\geq 4$ as good practice. And later applied chi Square accordingly. P value of 0.05 was considered significant. The good knowledge score could be due to the exposure of this girls to the media and awareness camps or they discuss it amongst themselves. Despite the fact that the mothers were not very highly educated in many cases. These findings are consistent with the results from studies done in Egypt and India. ${ }^{10,11}$ A possible explanation for this similarity may be that girls discuss menstruation and its hygiene with their friends and peers openly. The mass media play a prominent role in the dissemination of reproductive health information including menstruation. ${ }^{12-14}$ Table 3, adolescent girls constitute a vulnerable group not only with respect to their social 
status but also in relation to their health. In this regard, menstruation is regarded unclean or dirty in society. ${ }^{15}$ The cultural practices during menstruation differ from each region and community. In our study we found out that $91.9 \%$ girls took bath during menses giving a good practice score. However, the food restrictions during menses were profound and four hundred and sixty-four girls responded for food restrictions during menses. The rest of the girls $(53.6 \%)$ did not have any food restrictions. Similarly, $40.6 \%$ girls had religious restrictions during menses. An $87.8 \%$ respondents performed all the routine activities during menses. The findings unfold many practices: cultural and social restrictions associated with menstruation, myth, and misconception; the adaptability of the adolescent girls toward it; their reaction, reaction of the family; realization of the importance of awareness and scientific knowledge. Our results are similar to the study done by Kumar $\mathrm{A}$ et al. ${ }^{16}$ Various studies have reported similar observations regarding restrictions during periods in our country. ${ }^{17,18}$ All these studies show the various myths and taboos associated with menstruation in our society which can only be removed by health education and empowering the female child as these practices may have religious sentiments too. ${ }^{19-21}$ Majority of the girls were of the view that bath and personal hygiene are necessary during menstruation which was consistent with some previous studies. $^{22}$ Few studies have also shown that regular bathing is not practiced by many girls during menstruation which may be due to water scarcity, lack of knowledge, and lack of privacy. ${ }^{4}$ It was revealed that women cannot discuss openly at home about menstrual issues and they are considered unclean and untouchable during their menstrual periods. They are not allowed to carry out religious functions and not supposed to participate in the cooking during these periods. In spite of these restrictions, participants felt that they are acceptable to their family members during the menstrual period. ${ }^{23}$

Table 4 shows the attitude of respondants towards menstruation. Restrictions on going to temple and praying were seen in four hundred and fifteen respondants, restriction to enter kitchen was seen in only 61 girls whereas 81 did not have any opinion about it. Similarly, opinion about sleeping on same bed, touching pickle and washing hair was also seen as a positive attitude by majority of respondants. The score of positive feelings towards menstruation were $<26$ in the students and score of negative feelings was $>27$. This shows that in deed, attitudes and beliefs are a tool for shaping the health behaviors and may lead to incorrect behavior. So, the attitude and peformances of women in the field of menstruation are essential to promote health programs. ${ }^{18}$ The positive attitude of the adolescences towards menstrual process will help the female to take care of her selfcare during menses, maintain proper hygiene and go towards a healthy reproductive life. So, it seems that increasing of knowledge can be used in order to improve the attitude of menstruation in girls. Health education about the menstrual period should begin before the first menstrual period for physical and mental preparing of girls. ${ }^{19,20}$

Table 5 and 6 , corelate the socio demographic criteria to the attitude and practices of the respondants in this study. Both the tables show a positive correlation i.e. girls whose mother's education status secondary school and above were 1.51 times more likely had good knowledge about menstruation than their counterpart's educational status of the parents was important predictors of menstrual attitude and practice. ${ }^{24}$ In the present study girls whose mothers' educational statuses was secondary and above were two times more likely to have good practice of menstrual attitude than their counterparts. This aligns with the studies done in Ethiopia, Lebanon, India and Nigeria. ${ }^{14,21,24,25}$ The possible explanation might be that educated mothers may have awareness on practice and knowledge of menstruation and they may have provided materials for their daughters about care during menstruation. This is also true regarding the socioeconomic status .and the nuclear family status.

\section{CONCLUSION}

Authors conclude from present study that very few young girls between the age group 15 and 24 years did receive any information before the onset of menstruation. Among those who received some information, it was not adequate enough. The source of information was also not authentic. Both young and adult women agreed on this. Due to the inadequate knowledge on leads to many unnecessary restrictions on young girls and they faced many health problems and complaints, which were either ignored or managed inappropriately.

The role of the health sector was almost negligible in giving information to the management of health problems of these young girls.

This paper reemphasizes the important, urgent, and neglected need of providing correct knowledge to the entire community including adolescent and young girls. Correct knowledge will help them practice safe and hygienic menstrual practices and come out of traditional beliefs, misconceptions, and restrictions regarding menstruation. For this, the proper policies should be formulated and implemented, which can be part of overall health and community development policy. The physiology of the menstrual cycle, its connection to fertility, and the fact that menstruation is a normal process without any kinds of dirt should be part of family life/sexual education in schools. The health sector especially the public health system should play proactive role.

\author{
Funding: No funding sources \\ Conflict of interest: None declared \\ Ethical approval: The study was approved by the \\ Institutional Ethics Committee
}




\section{REFERENCES}

1. Cronje HS, Kritzinger IE. Menstruation: symptoms, management and attitudes in university students. Int J Gynaecol Obstet.1991;35(2):147-50.

2. The Lancet. Time to talk about menstruation: \#PeriodEmoji. Lancet 2017; 389: 2264.

3. Sommer M, Caruso BA, Sahin M, Calderon T, Cavill $\mathrm{S}$, Mahon $\mathrm{T}$, et al. A time for global action: addressing girls' menstrual hygiene management needs in schools. PLoS Med. 2016;13(2):e1001962.

4. van Eijk AM, Sivakami M, Thakkar MB, Bauman A, Laserson KF, Coates $\mathrm{S}$, et al. Menstrual hygiene management among adolescent girls in India: a systematic review and meta-analysis. BMJ open. 2016;6(3):e010290.

5. Tegegne T, Sisay M. Menstrual hygiene management and school absenteeism among female adolescent students in Northeast Ethiopia. BMC Public Health 2014,14(1118).

6. Upashe SP, Tekelab T, Mekonnen J. Assessment of knowledge and practice of menstrual hygiene among high school girls in Western Ethiopia. BMC Women's Health. 2015;15(1):84.

7. Dudeja P, Sindhu A, Shankar P, Gadekar T. A crosssectional study to assess awareness about menstruation in adolescent girls of an urban slum in western Maharashtra. Int $\mathbf{J}$ Adolescent Med Health. 2016;30(4).

8. Kuhlmann, Sebert A, Henry, Kaysha, Wall, Lewis L. Menstrual hygiene management in resource-poor countries. Obstetr Gynecol Survey. 2017;72(6):35676.

9. Abioye EA. Menstrual knowledge and practices amongst secondary school girls in Ile Ife, Nigeria. J R Soc Health. 2000;20:23-6.

10. El-Gilanya A, Badawib K, EL-Fedawyb S. Menstrual hygiene among adolescent school girls in Mansoura, Egypt. Reprod Health Matter. 2005; 13:147-52.

11. Bhattacherjee S, Ray K, Biswas R, Chakraborty M. Menstruation. Experiences of adolescent slum dwelling girls of siliguri city, west Bengal. India. J Basic Clinic Reprod Sci. 2013;2(2):85-91.

12. Adinma ED, Adinma JI. Perceptions and practices on menstruation amongst Nigerian secondary school girls. Afr J Reprod Health. 2008;12(1):74-83.

13. Narayan KA, Srinivasa DK, Pelto PJ, Veerammal S. Puberty rituals, reproductive knowledge and health of adolescent schoolgirls in South India. Asia-Pac Popul J. 2001;16(2):225-38.

14. Oche O, Umar S, Gana J, Ango T. Menstrual health: the unmet needs of adolescent girls' in Sokoto, Nigeria. Sci Res Essays. 2012;7(3):410-8.

15. Dasgupta A, Sarkar M. Menstrual hygiene: How hygienic is the adolescent girl? Indian J Community Med. 2008;33(2):77-80.
16. Kumar A, Srivastava K. Cultural and social practices regarding menstruation among adolescent girls. Soc Work Public Health. 2011;26(6):594-604.

17. Thakur H, Aronsson A, Bansode S, Stalsby Lundborg C, Dalvie S, Faxelid E. Knowledge, practices, and restrictions related to menstruation among young women from low socioeconomic community in Mumbai, India. Frontiers Public Health. 2014;2:72.

18. Fakhri M, Hamzehgardeshi Z, Golchin NA, Komili A. Promoting menstrual health among Persian adolescent girls from low socioeconomic backgrounds: a quasi-experimental study. BMC Public Health 2012;12(1):19319.

19. Brantelid IE, Nilvér H, Alehagen S. Menstruation During a Lifespan: A Qualitative Study of Women's Experiences. Health care for women international 2014;35(6):600-16.

20. Chan S, Yiu K, Yuen P, Sahota D, Chung T. Menstrual problems and health-seeking behaviour in Hong Kong Chinese girls. Hong Kong Med J. 2009;15(1):18-23.

21. Shanbhag D, Shilpa R, D'Souza N, Josephine P, Singh J, Goud BR. Perceptions regarding menstruation and practices during menstrual cycles among high school going adolescent girls in resource limited settings around Bangalore city, Karnataka, India. Int $\mathbf{J}$ Collab Res Int Med Public Health. 2012;4:1354-62.

22. Garg S, Anand T. Menstruation related myths in India: Strategies for combating it. J Family Med Prim Care. 2015;4:184-6.

23. Nagaraj C, Konapur KS. Effect of health education on awareness and practices related to menstruation among rural adolescent school girls in Bengaluru, Karnataka. Int J Prev Public Health Sci. 2016;2:1821.

24. Santina T, Wehbe N, Ziade FM, Nehme M. Assessment of beliefs and practices relating to menstrual hygiene of adolescent girls in Lebanon. Int J Health Sci Res. 2013;3(12):75-88.

25. Patavegar BN, Kapilashrami MC, Rasheed N, Pathak R. Menstrual hygiene among adolescent school girls: an in-depth cross-sectional study in an urban community. Int J Health Sci Res. 2014;4(11):15-21.

Cite this article as: Deshmukh V, Sandhu GK, Rachakonda L, Kakde M, Andurkar SP. Knowledge, attitudes and practices (KAP) regarding menstruation among girls in Aurangabad, India and their correlation with sociodemographic factors. Int $\mathbf{J}$ Reprod Contracept Obstet Gynecol 2019;8:979-87. 